\title{
Ecuadorian kindergartners' numerical development: contribution of SES, quality of early mathematics education, and school type ${ }^{1}$
}

\author{
Gina Bojorque ${ }^{2}$ \\ Joke Torbeyns ${ }^{3}$ \\ Daniël Van Nijlen ${ }^{4}$ \\ Lieven Verschaffe ${ }^{5}$
}

\section{Abstract}

This study aimed at analyzing the development of Ecuadorian children's early numerical abilities during the Kindergarten year in relation to their SES, the quality of their early mathematics education, and the attended school type. 179 Ecuadorian Kindergartners (18 classrooms, 6 classrooms per school type) were offered a standards-based early numeracy test at both the start and the end of the Kindergarten year. In all classrooms, the quality of early mathematics education was assessed twice via the COEMET instrument. Results first showed rather low scores on the early numeracy test, with only 50\% (at the start) up to $70 \%$ (at the end) of the items solved correctly, along with large inter-individual differences in these scores. Second, the quality of early mathematics education in the participating classrooms was also rather low. Third, children's early numerical abilities at Kindergarten entry, SES, and school type predicted children's early numerical abilities at the end of the school year. The quality of early mathematics education did not contribute to children's numerical development. We critically discuss our findings in view of optimizing the quality of Ecuadorian early mathematics education as a stepping stone towards enhanced numerical development.

\section{Keywords}

Early numerical abilities - Quality of early mathematics education - SES - Kindergarten.

\footnotetext{
1- This work was supported by a scholarship sponsored by the Ecuadorian Secretary of Higher Education, Science, Technology and Innovation (SENESCYT).

2- Center for Instructional Psychology and Technology, KU Leuven, Belgium and University of Cuenca, Ecuador. Contact: gina.bojorque@ucuenca.edu.ec

3- Center for Instructional Psychology and Technology, KU Leuven, Belgium. Contact: joke.torbeyns@kuleuven.be

4- Center for Educational Effectiveness and Evaluation, KU Leuven, Belgium. Contact: daniel.vannijlen@kuleuven.be

5- Center for Instructional Psychology and Technology, KU Leuven, Belgium. Contact: lieven.verschaffel@kuleuven.be
} 


\section{Desenvolvimento numérico de pré-escolares equatorianos: o papel do nível sócio econômico, da qualidade da educação matemática inicial e do tipo de escola}

\section{Resumo}

Este estudo teve como objetivo analisar o desenvolvimento de habilidades numéricas iniciais entre crianças equatorianas durante a pré-escola, em relação a seu status sócio econômico (SES), à qualidade da sua educação matemática inicial e ao tipo de escola frequentada. 179 pré-escolares equatorianos (18 classes, sendo 6 por tipo de escola) responderam um teste padronizado sobre numeramento inicial, tanto no começo quanto ao final do ano escolar. Em todas as salas de aula a qualidade da educação matemática inicial foi medida duas vezes por meio do instrumento COEMET. Em primeiro lugar, os resultados mostraram pontuações bastante baixas no teste de numeramento inicial, com apenas 50\% (no inicio) e 70\% (no final) dos itens resolvidos corretamente, ao lado de grandes diferenças interindividuais nesses escores. Em segundo lugar, a qualidade da educação matemática inicial nas salas de aula participantes também foi bastante baixa. Em terceiro lugar, as habilidades numéricas iniciais das crianças na entrada da préescola, o nível socio econômico (SES) e o tipo de escola foram preditores das habilidades numéricas das crianças no final do ano letivo. A qualidade da educação matemática inicial não contribuiu para o desenvolvimento das crianças em numeramento. Discutimos criticamente nossas descobertas com vistas a otimizar a qualidade da educação matemática inicial equatoriana, como um passo para melhorar o desenvolvimento das habilidades numéricas.

\section{Palavras chave}

Habilidades numéricas iniciais - Qualidade da educação matemática inicial - Nível sócio econômico (SES) - Pré-escola.

\section{Introduction}

Young children's early numerical abilities are important for their further mathematical development and their future professional activities (GEARY, 2011). However, previous studies indicate that even before the start of formal education there are large individual differences in these numerical abilities (ANDERS et al.,

6- Este trabalho foi financiado pela Secretaria de Educação Superior, Ciência, Tecnologia e Inovação do Equador (SENESCYT). 
2012; DUNCAN et al., 2007; RAMANI; SIEGLER, 2011). These differences are related to both individual and contextual factors, including children's socio-economic status (SES) (CLEMENTS; SARAMA, 2008; JORDAN et al., 2006) and the quality of early mathematics education they receive (CLEMENTS; SARAMA, 2008; FUSON, 2004). Unfortunately, hardly anything is known about Ecuadorian children's early numerical development. Given the overall poor performance of Ecuadorian elementary and secondary school students at national (INEVAL, 2014) and international (TERCE, 2008) mathematics assessments, we aimed at analyzing Ecuadorian Kindergartners' early numerical development, in relation to their individual (i.e., early numerical abilities at the start of the school year) and contextual (i.e., SES, quality of early mathematics education and school type) characteristics.

\section{Early numerical abilities}

Before the onset of formal schooling young children develop foundational numerical abilities, which help them to make sense of the world, and act as stepping stones towards their mathematical development at school (FUSON, 2004; GINSBURG, 2014; SARAMA; CLEMENTS, 2009a). According to Sarama and Clements (2009a), children's early numerical development covers various abilities, including subitizing, counting, comparing and ordering, composing and decomposing, and adding and subtracting ${ }^{7}$. Subitizing refers to the ability to immediately determine the exact numerosity of a small number of objects without counting them. At the age of 5, most children are able to instantly recognize up to five objects ${ }^{8}$. Counting involves learning the number word sequence and finding out the number of items in a set (which includes knowing that the last counting word indicates "how many"). Most 5-year-olds are able to count and accurately produce item sets up to 10, and to count backward from 10 to 1 . to the children's ability to determine which of two (or more) groups is bigger (the biggest) or smaller (the smallest), and to order groups on the basis of their magnitude. The majority of 5-yearolds can compare item sets up to five and can identify and use ordinal numbers from "first" to "tenth". Composing and decomposing are complementary: composing involves mentally or physically combining small groups of objects (e.g., 4 plus 2 cookies makes 6 cookies), whereas decomposing implies breaking a group into parts (e.g., 6 cookies is made up of 4 cookies plus 2 cookies). At the age of 5, most children can compose and decompose numbers up to five. Finally, adding and subtracting involves knowing that a collection can be made larger or smaller by adding or respectively removing objects to or from it. Most 5-year-olds are able to solve addition and subtraction problems up to 10 using objects or fingers. Additionally, Sarama and Clements (2009a) mention that children's ability to read and write numerals is an important early numerical ability, but should be accompanied by the ability to functionally use the written representations of

\footnotetext{
7- For a slightly different categorization of the components of children's early numerical development, see Sayers and Andrews (2015).

8- Given the scope of our study, we focus on the most important numerical abilities for 5 -year-olds, based on the learning trajectories developed by Sarama and Clements (2009a).
} 
numbers. At the age of 5, most children are able to read and write numerals to represent and communicate quantity.

Unfortunately, children do not have equal opportunities to develop their early numerical abilities and therefore greatly differ in the abilities they bring to elementary school (ANDERS et al., 2012; DUNCAN et al., 2007; RAMANI; SIEGLER, 2011). This is problematic given the abundant evidence that early numerical abilities contribute to later mathematics learning (AUNIO; NIEMIVIRTA, 2010; DE SMEDT; VERSCHAFFEL; GHESQUIĖRE, 2009; DUNCAN et al., 2007; JORDAN et al., 2009; KRAJEWSKY; SCHNEIDER, 2009).

\section{Socio-economic status}

Prior research has established consistent relations between children's socioeconomic status (SES) and their early numerical achievement (CLEMENTS; SARAMA, 2011; JORDAN et al., 2006; STARKEY; KLEIN; WAKELEY, 2004). For instance, Starkey et al. (2004) reported that, even before the start of Kindergarten, children from middleSES background outperform children from low-SES background on early number tasks (including counting, number comparison, ordinal number terms, and addition and subtraction). Similarly, Jordan et al. (2006) found that low-SES Kindergartners performed poorly on number tasks (including verbal calculation, i.e., story problems, and nonverbal calculation, i.e., problems presented non-verbally with visual referents) as compared to middle-SES peers. Moreover, during Kindergarten, children from both SES groups made similar progression in their nonverbal calculation ability, but low-SES children developed their verbal calculation ability more slowly than their higher-SES peers. Likewise, Clements and Sarama (2011) reported limited subitizing abilities of low-SES children before Kindergarten entry, with hardly 15\% of the children subitizing up to 4 . In sum, children of low-SES groups enter formal schooling with specific gaps in their numerical abilities and are therefore at risk for continued low achievement in elementary school (JORDAN et al., 2009).

These SES-related differences in early numerical abilities might be due to initial differences in the quantity and quality of early mathematics experiences at home. Hence, Starkey et al. (2004) found that middle-SES parents tend to engage their children more often in complex mathematical activities than low-SES parents. Likewise, Clements and Sarama (2007) observed that low-SES parents less frequently engage in mathematical activities and are less supportive for children's mathematical development than middleSES parents.

\section{Quality of early mathematics education}

There is ample evidence that the quality of early mathematics education significantly influences students' outcomes (CARPENTER et al., 1989; HIEBERT; GROUWS, 2007; KILDAY; KINZIE, 2009). The quality of early educational settings has been defined and assessed in a variety of ways (PIANTA et al., 2005) making 
it difficult to compare the results of different studies and formulate general conclusions. There are a number of instruments specifically designed to assess the quality of mathematics teaching, differing in target age and focus (KILDAY; KINZIE, 2009). As discussed by Kilday and Kinzie (2009), the Classroom Observation of Early Mathematics Environment and Teaching (COEMET) is an instrument that is based on research about characteristics and teaching strategies of effective teachers of early childhood mathematics, and that is specifically designed to assess the quality and quantity of mathematics instruction in early education settings in terms of teaching strategies, mathematics content, clarity and correctness of mathematics teaching, and quality of student/teacher interactions.

Recent studies of Clements and colleagues (e.g., CLEMENTS et al., 2011; SARAMA et al., 2008) indicated that classrooms characterized by higher-quality mathematics instruction as evidenced by the COEMET more effectively enhanced young children's mathematical development than classrooms of lower-quality mathematics instruction. Teachers providing high-quality mathematics instruction were more responsive to children, were characterized by the belief that mathematics learning can be enjoyable and were enthusiast for mathematics; moreover, they understood and taught developmentally appropriate mathematics and used effective management and instructional strategies (CLEMENTS et al., 2011; SARAMA et al., 2008).

In line with the latter, Clements and colleagues (CLEMENTS et al., 2013) found that children from low-resource communities who experienced high-quality, research-based mathematics teaching by means of implementing the TRIAD (Technology-enhanced, Research-based, Instruction, Assessment, and professional Development) scale up model from preschool to grade 1, more fluently acquired early numerical abilities than their peers who did not experience such instruction. Although it is important to provide high-quality early mathematics instruction to all children in view of enhancing their early numerical development, this is particularly relevant for low-SES children as it might help to reduce the SES-related gap in mathematical achievement (CLEMENTS; SARAMA, 2011).

\section{The Ecuadorian context}

Unfortunately, little is known about the development of Ecuadorian Kindergartners' early numerical abilities as well as its relation to their SES and the quality of their early mathematics education. Since all previous studies have been conducted in North America and Europe, the results available cannot be generalized to Ecuador, given its status of a developing country (UNITED NATIONS, 2016) and thus substantially differing from more developed nations in terms of cultural, societal, economic and educational characteristics. Specifically related to the socio-economic characteristics, the latest socio-economic study (INEC, 2011) conducted in the urban areas of the five main cities of Ecuador sheds light on the population distribution by SES. The numbers indicate that only $1.9 \%$ of the Ecuadorian population belongs to the upper-SES level; $11.2 \%$ is within the upper-middle-SES level; $22.8 \%$ belongs to the mid-middle-SES level; $49.3 \%$ is within the lower-middle-SES level; 
and 14.8\% belongs to the lower-SES level. Precise data on the population distribution by SES in the rural areas do not exist, but it was reported that $47.3 \%$ of this population lives in poverty (INEC, 2014).

With respect to Ecuador's educational characteristics, the educational system comprises three levels: Beginning level (for children up to 5 years); Basic Education (from Kindergarten or grade 1, up to grade 10, for children aged 5 to 14 years) and High School (last three years of schooling, for students aged 15 to 17 years). Kindergarten education in Ecuador serves 5- to 6-year-olds and is compulsory nationwide. Kindergartens are regulated by the Ministry of Education, which issues a national mandatory curriculum that prescribes the minimum requirements that children should master in all domains, including mathematics. Education at this level is provided for by the public and private sectors, with 73\% of the children attending public schools (39\% attend public urban schools; 34\% attend public rural schools), 21\% attending private schools; the remaining $6 \%$ of the children attending municipal schools or schools financially assisted by both government and private sources (ECUADOR, 2013). The quality of instruction in the country is generally assumed to be quite different across these different school types, with private schools offering higher-quality education than public urban schools, and public urban schools providing higher-quality instruction than public rural schools (PREAL, 2006).

\section{The present study}

To the best of our knowledge, only one study investigated Ecuadorian Kindergartners' early numerical abilities (BOJORQUE et al., 2015). Using an early numerical abilities test based on the Ecuadorian educational standards for Kindergarten mathematics (number and arithmetic), Bojorque et al. (2015) found that at the end of preschool (which coincides more or less with the start of Kindergarten), children were able to correctly answer about $40 \%$ of the items. At the end of Kindergarten, children were able to correctly solve about 70\% of the items. Moreover, Bojorque et al. did not only observe inter-individual differences in children's test scores but also provided tentative evidence for performance differences between the different school types, with highest performances for children attending private schools. As outlined above, national and international assessments evidence a low performance of Ecuadorian elementary and secondary school students. This low performance might be related to difficulties in early numerical development. Therefore, we aimed at investigating the development of Ecuadorian Kindergartners' early numerical abilities in relation to their individual and contextual characteristics by addressing three research questions:

1. How well do Ecuadorian Kindergartners perform on a standards-based early numerical abilities test at the start and at the end of the Kindergarten year?

2. What is the quality of early mathematics education in Ecuadorian Kindergartens? 
3. Do children's numerical abilities at the start of Kindergarten, their SES, the quality of their early mathematics education and the type of school they attend contribute to their numerical development during the Kindergarten year?

\section{Method}

\section{Participants}

The participants were 179 Ecuadorian Kindergartners (92 boys, 87 girls) randomly selected from 18 schools of the three major school types in Ecuador (six schools per type, one class per school, about 10 children per class), resulting in 59 children coming from public urban schools, 62 children coming from public rural schools, and 58 children coming from private schools. At the beginning of the study, the mean age of the children was 5 years 2 months ( $S D=4$ months).

We used the mothers' educational level as indicator of children's SES (cf. STARKEY et al., 2004). We distinguished among five levels of maternal education, i.e., (1) no education, (2) elementary education, (3) high school education, (4) bachelor's degree, and (5) post bachelor's degree. Table 1 describes the number of children, their age and SES per school type. Multilevel analysis (with children nested within classrooms) indicated that there were differences in children's SES between the three school types, $\mathrm{F}(2,14.949)=17.655, \mathrm{p}<.001$, with children who attended private schools belonging to a higher SES level than children attending public (urban and rural) schools.

Table 1 - Number of children, mean age and SES per school type.

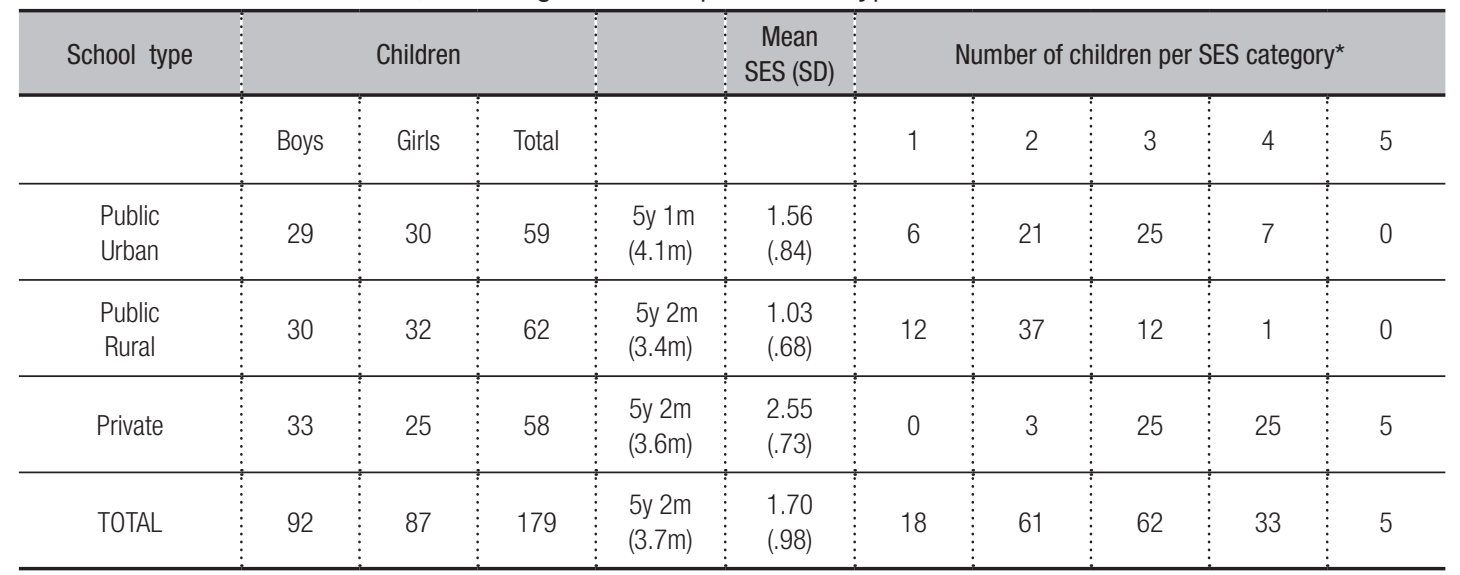

${ }^{*} 1$ = no education, 2 = elementary education, 3 = high school education, 4 = bachelor's degree, 5 = post bachelor's degree.

Source - Authors. 


\section{Measures}

We assessed children's numerical abilities via the Test of Early Number and Arithmetic (TENA; BOJORQUE et al., 2015). The quality of early mathematics education was assessed with the COEMET instrument - Classroom Observation of Early Mathematics Environment and Teaching (SARAMA; CLEMENTS, 2009b).

\section{Test of Early Number and Arithmetic}

The Test of Early Number and Arithmetic TENA (BOJORQUE et al., 2015) is a test based on the Ecuadorian national standards for Kindergarten number and arithmetic. This test is composed of 54 items divided over nine subscales, namely (1) Quantifiers, (2) One-to-one correspondence, (3) Order relations more than/less than, (4) Counting, (5) Quantity identification and association with numerals, (6) Ordering, (7) Reading and writing numerals, (8) Addition, and (9) Subtraction. Each subscale consists of six items ordered according to a progressive level of complexity. The test has two parts: an individual part with 29 items that mainly require an oral response (12 tasks require the use of small blocks for children to manipulate or for the examiner to present the task), and a collective part with 25 items that require the use of a paper and pencil.

Items are scored dichotomously, with a score of 1 indicating a correct answer and a score of 0 an incorrect one (maximum score $=54$ ). A study focusing on the psychometric qualities of the TENA (BOJORQUE et al., 2015) demonstrated, first, high overall reliability (Cronbach's $\alpha=.91$ ), but lower reliability at the subscale level. Second, TENA's concurrent validity with the Early Numeracy Test - ENT (VAN DE RIJT at al., 1999) was high ( $\mathrm{n}=50, \mathrm{r}=.89, \mathrm{p}=.01$ ). Third, a panel of 10 experts in the domain of early number and arithmetic provided evidence for TENA's content validity, as all items were judged as measuring the curriculum content at a very good level. For the present study, Cohen's Kappa (on 10\% of the data) revealed strong inter-rater reliability of the scoring at the item level, $\mathrm{K}=.92, \mathrm{p}<.001$.

\section{Quality of early mathematics education}

The quality of early mathematics education was assessed twice via the Classroom Observation of Early Mathematics Environment and Teaching instrument - COEMET (SARAMA; CLEMENTS, 2009b). The COEMET is a half-day administration instrument specifically designed to assess the quality of mathematics education in early education settings. The instrument has 28 items addressing the quality of the Classroom Culture (CC) (9 items) and the Specific Mathematical Activities (SMA) (19 items) on a five-point Likert scale ranging from "strongly disagree" to "strongly agree". Within the CC section, two different dimensions are distinguished, namely (a) environment and interactions and (b) teacher's personal attributes. An example of a CC item is: "The environment showed signs of mathematics: Materials for mathematics, including specific math manipulatives, were available and mathematics was enacted and/or discussed around 
them". With respect to the SMA, the COEMET distinguishes among seven dimensions, namely (a) mathematical focus, (b) organization, teaching approaches, interactions, (c) expectations, (d) eliciting children's solution methods, (e) supporting children's conceptual understanding, (f) extending children's mathematical thinking, and (g) assessment and instructional adjustment. An example of a SMA item is: "The teacher began by engaging and focusing children's mathematical thinking (i.e., directed children's attention to, or invited them to consider, a mathematical question, problem, or idea)". The inter-rater reliability (on 10\% of the data) of COEMET scores was $K=.88, p<.001$.

\section{Procedure}

The TENA was administered in the first month (September) and in the last (June) month of the school year. Children were tested in a separate room in their own school. All children started with the collective part of the test. The 18 classes were observed and videotaped by two observers in the sixth (February) and in the ninth (May) month of the school year using the COEMET. For each of these two observation moments, observers spent half-day in each classroom from the beginning of the activities until lunch time, including the observation of a mathematics lesson. This procedure is in line with the procedural instructions of the designers of the instrument (cf. SARAMA; CLEMENTS, 2009b). Observers took field notes and completed the COEMET scoring form based on the notes and videos of the lessons.

\section{Data analyses}

All descriptive and inferential statistical analyses were conducted via IBM SPSS Statistics version 20.0. Taking into account the nested structure of our data (i.e., children nested within classrooms), we conducted multilevel analyses using SPSS Mixed (HAYES, 2006).

\section{Results}

The results are presented along our three research questions. First, we describe children's performances on the TENA at the start and at the end of Kindergarten. Next, we present the COEMET results for the participating classrooms. Finally, we report on the contribution of children's numerical abilities at the start of Kindergarten, their SES, the quality of early mathematics education and the school type to children's numerical abilities at the end of Kindergarten.

\section{Ecuadorian children's early numerical abilities}

To get a view on the early numerical abilities of Ecuadorian children at the start and the end of the Kindergarten year (research question 1), we present the descriptive statistics of children's TENA's scores at the two measurements. As can be derived from 
Table 2, at the start of Kindergarten, Ecuadorian children correctly solved less than half of the items (i.e., 44\%). As the TENA primarily aims at measuring Kindergartners' mastery of the educational standards at the end of the Kindergarten year, these results were not surprising. We also found large inter-individual differences in TENA scores, with some children correctly answering only two items and others correctly responding to up to 49 items. A multilevel analysis on children's TENA scores at the start of the Kindergarten year revealed a significant difference in TENA scores between the school types, $F(2,14.755)=6.967, \mathrm{p}<.05$, demonstrating higher test scores for children from private schools than for their peers from public rural schools. No other differences were found between school types.

Next, and as also shown in Table 2, children correctly solved about 70\% of the items at the end of Kindergarten. We again found large individual differences in TENA scores, with some children correctly solving only seven items and other children doing well on up to 52 items. A multilevel analysis on children's TENA scores at the end of the Kindergarten year indicated significant school type differences, $F(2,14.804)=$ $4.768, p<.05$. As was the case at the start of the year, differences were found between children in private schools and children in public rural schools, but not between the other school types.

To analyze whether children grew in their early numerical abilities during the Kindergarten year, we conducted a multilevel analysis with the difference in gain score (i.e., the difference between the score at the start and at the end of the Kindergarten year) as the dependent variable and no predictor. The results indicated that on average, children's performance increased with 13.67 points, $\mathrm{t}(17.166)=20.066, \mathrm{p}<.001$.

Additionally, we compared the growth in children's early numerical abilities between the three school types during the school year by analyzing the difference in gain scores using multilevel analysis. This analysis indicated that there were no differences in TENA gain scores between the three school types, $F(2,14.953)=1.379$, $p$ $=.282$. These results indicate that the progression in early numerical abilities between the start and the end of the Kindergarten year was the same for children from the different school types.

Table 2- Mean, standard deviation and range of TENA scores at the start and the end of the school year per school type (max. score $=54$ )

\begin{tabular}{|c|c|c|c|c|c|c|}
\hline & \multicolumn{3}{|c|}{ Start of Kindergarten } & \multicolumn{3}{|c|}{ End of Kindergarten } \\
\hline & M & SD & Range & M & SD & Range \\
\hline Public Urban & 23.17 & 8.34 & $2-47$ & 37.36 & 9.38 & $7-52$ \\
\hline Public Rural & 19.82 & 6.18 & $6-33$ & 34.55 & 7.27 & $10-47$ \\
\hline Private & 28.93 & 9.08 & $5-49$ & 40.98 & 8.08 & $10-52$ \\
\hline TOTAL & 23.88 & 8.74 & $2-49$ & 37.56 & 8.64 & $7-52$ \\
\hline
\end{tabular}

Source: Authors. 


\section{Quality of early mathematics education in Ecuadorian Kindergarten}

As mentioned above, the quality of early mathematics education was assessed twice via the COEMET instrument. Because the scores for the two observation moments were highly correlated, Spearman's rho $=.80, p=.01$, we used the mean COEMET score for these two observations in all our analyses. To describe the quality of early mathematics education in Ecuadorian Kindergarten (research question 2), we computed the means, standard deviations and range of the overall COEMET scores as well as the COEMET subscale scores (CC, SMA) per school type. As demonstrated in Table 3, the quality of early mathematics education tended to be low in the observed classrooms, i.e., hardly half of the maximum score per subscale as well as for the COEMET as a whole. Typically, teachers' approach involved mainly whole-class and teacher-centered instruction supported by paper-and-pencil work sheets, with scarce individual teacher-child or child-child interactions, thought-provoking discussions or child-initiated activities. ANOVA on the overall COEMET scores revealed no significant differences between the school types, $F(2,15)=1.210, p=.326$. The descriptive statistics in Table 3 suggest somewhat more variation in the quality of early mathematics education offered in private schools than in public urban and public rural schools.

Table 3- Means, standard deviations and range of COEMET scores per school type.

\begin{tabular}{|c|c|c|c|c|c|c|c|c|c|}
\hline & \multicolumn{3}{|c|}{$\begin{array}{l}\text { Classroom Culture } \\
\quad(\max .=45)\end{array}$} & \multicolumn{3}{|c|}{$\begin{array}{l}\text { Specific Math Activities } \\
(\max .=95)\end{array}$} & \multicolumn{3}{|c|}{$\begin{array}{l}\text { Total COEMET } \\
(\max .=140)\end{array}$} \\
\hline & M & SD & Range & M & SD & Range & M & SD & Range \\
\hline Public Urban & 16.67 & 3.09 & 13.5-22 & 41.52 & 6.20 & $34-51$ & 58.19 & 8.41 & $48.5-68$ \\
\hline Public Rural & 13.17 & 3.43 & $10-17.5$ & 36.38 & 5.46 & 29-44 & 49.54 & 8.74 & 40-61.5 \\
\hline Private & 16.42 & 6.23 & $9.5-24.5$ & 40.98 & 7.88 & $32.25-51$ & 57.40 & 13.88 & $44.75-74.5$ \\
\hline Private & 15.42 & 4.52 & $9.5-24.5$ & 39.63 & 6.63 & $29.5-51$ & 55.04 & 10.77 & $40-74.5$ \\
\hline
\end{tabular}

Source: Authors.

\section{Association between numerical abilities, SES, quality of early mathematics education and school type}

To analyze to what extent children's early numerical abilities at the start of Kindergarten, their SES, the quality of early mathematics education and the attended school type contribute to children's numerical development during the Kindergarten year (research question 3), we evaluated the adequacy of four different multilevel models for predicting children's TENA scores at the end of the year, namely (a) TENA Test 1 (Model 1); (b) TENA Test 1 and SES (Model 2); (c) TENA Test 1, SES and COEMET9 (Model 3); (d)

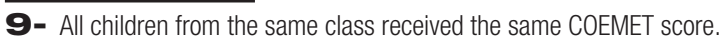


TENA Test 1, SES, COEMET and School Type (Model 4). Table 4 summarizes the results per model.

Table 4. - Multilevel model of predictors of TENA scores at the end of the school year.

\begin{tabular}{|c|c|c|c|c|c|c|c|}
\hline Model & Variable & Coeff. & SE & df & $p$-value & Sig. & $-2 \mathrm{LL}$ \\
\hline \multirow[t]{2}{*}{1} & Intercept & 18.271 & 1.297 & 94.566 & & & 1104.28 \\
\hline & TENA Test 1 & 0.808 & 0.049 & 151.672 & .000 & $\star * *$ & \\
\hline \multirow[t]{3}{*}{2} & Intercept & 14.864 & 1.500 & 69.936 & & 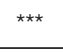 & 1086.73 \\
\hline & TENA Test 1 & 0.652 & 0.061 & 173.243 & .000 & $* * \star$ & \\
\hline & SES & 2.641 & 0.614 & 145.421 & .000 & 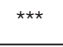 & \\
\hline \multirow[t]{4}{*}{3} & Intercept & 18.924 & 3.522 & 14.193 & & $\star \star \star *$ & 1088.72 \\
\hline & TENA Test 1 & 0.654 & 0.061 & 172.764 & .000 & 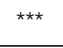 & \\
\hline & SES & 2.812 & 0.626 & 154.405 & .000 & 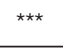 & \\
\hline & COEMET & -0.083 & 0.065 & 15.432 & .217 & & \\
\hline \multirow[t]{6}{*}{4} & Intercept & 14.206 & 3.796 & 16.757 & & 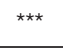 & 1076.86 \\
\hline & TENA Test 1 & 0.646 & 0.060 & 172.850 & .000 & 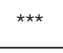 & \\
\hline & SES & 3.388 & 0.663 & 172.678 & .000 & 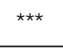 & \\
\hline & COEMET & -0.068 & 0.061 & 14.667 & .287 & & \\
\hline & Public urban & 3.481 & 1.531 & 17.507 & .036 & * & \\
\hline & Public rural & 3.985 & 1.666 & 19.633 & .027 & * & \\
\hline
\end{tabular}

Note. $R^{2}=.62$ (Model 1); $R^{2}=.65($ Model 2$) ; R^{2}=.65$ (Model 3); $R^{2}=.67$ (Model 4); ${ }^{*} p<.05,{ }^{\star * \star} p<.001$.

Source: Authors.

As shown in Table 4, children's numerical abilities at the end of the Kindergarten year were predictively related to their numerical abilities at the start of that year (Model 1). More specifically, 62\% of the variance in children's numerical abilities at the end of the Kindergarten year can be accounted for by their numerical abilities at the start of the year. Adding children's SES as a predictor to the multilevel analyses (Model 2) resulted in a small but significant $(p<.001)$ increase of $3 \%$ of the explained variance in numerical abilities at the end of the year, meaning that children's SES contributed to their numerical abilities at the end of the year even when children's numerical abilities at the start of the year were statistically controlled for. Adding the quality of early mathematics education as the third predictor to the analyses (Model 3), we found no further increase in the amount of explained variance $(p=.846)$, indicating that the quality of early mathematics education received during the Kindergarten year did not predict children's numerical abilities at the end of the year. Finally, adding school type to the model (Model 4) resulted in a small but significant increase of 2\% of the explained variance in children's numerical abilities at the end of the year. The contribution of public urban and public rural schools was significant $(p<.05)$, indicating that after 
taking into account children's early numerical abilities at the start of Kindergarten and SES, children in public urban and public rural schools made more progress in their early numerical abilities than children in private schools.

\section{Discussion}

Although the claim that young children's numerical abilities are fundamental for their future mathematical achievement is well-documented in the international research literature, little is known about Ecuadorian Kindergartners' early numerical development. Prior studies on early numerical abilities have been conducted mainly in North America and Europe (e.g., ANDERS et al., 2012; AUNIO; NIEMIVIRTA, 2010; DE SMEDT et al., 2009; FUSON, 2004; GINSBURG, 2014; JORDAN, et al., 2006; SARAMA; CLEMENTS, 2009a), making it difficult to generalize their results to countries outside these regions, and particularly less developed countries such as Ecuador. Therefore, we aimed at analyzing the development of Ecuadorian children's early numerical abilities during the Kindergarten year.

To achieve this aim, we first described Ecuadorian children's numerical abilities at the start and at the end of Kindergarten, using a standards-based early numerical abilities test (research question 1). We also examined the quality of early mathematics education that these children received throughout the Kindergarten year via the COEMET instrument (research question 2). Finally, we looked at the contribution of children's numerical abilities at the start of Kindergarten, their SES, the quality of early mathematics education they received, and the attended school type to children's numerical abilities at the end of Kindergarten (research question 3). Hereafter, we summarize and discuss the major findings and reflect on their theoretical, methodological and educational implications.

\section{Ecuadorian children's early numerical abilities at the start and at the end of Kindergarten}

A first major finding relates to Ecuadorian Kindergartners' early numerical abilities at the start and the end of the school year. In line with Bojorque et al. (2015), we found that, at Kindergarten entry, children correctly solved less than half of the items and largely differed in their abilities, with some children having acquired hardly any, whereas others have developed most of the numerical abilities expected to be mastered at the end of Kindergarten. Although children progressed in their numerical abilities during the Kindergarten year, with about 3/4 of the items correctly solved at the end of Kindergarten, we again observed large inter-individual differences at the end of the year. These findings add to our understanding of Ecuadorian children's early numerical development, as this is the first study that systematically followed this development using a standards-based early numeracy test. But, they also raise concerns regarding the feasibility of the national standards for early mathematics education in Ecuador for all children, given the large inter-individual differences in children's performances at the end of the Kindergarten year. Although in this study we evaluated children's early numerical abilities via a reliable and valid test, it is important 
to note that the use of standardized tests with young children is a controversial and (thus) debated issue. First, some scholars argue that teachers should avoid using and relying on standardized tests in kindergarten as this practice involves some problems including teachers' focus on preparing children to excel on these tests even already at such an early age, or that children have restricted time for recess (e.g., JEYNES, 2006). Second, relying on standardized tests may also result in misrepresenting what young children actually know and are capable of doing, because the standardized (and, in many cases, paper-based) nature of these tests may result in a serious underestimation of - particularly young - children's mathematical abilities (WAGER; GRAUE; HARRIGAN, 2016). Thus, the use of appropriate conversational interviewing techniques and meaningful tasks would be necessary to elicit those mathematical abilities (PERRY; MACDONALD; GERVASONI, 2015). Against these critical comments about the early use of standardized tests in young children is the claim of other scholars who argue in favor of their use, as long as these assessment methods are developmentally appropriate and culturally and linguistically responsive (NAEYC, 2003). For instance, English (2016) argues that although we cannot rely uniquely on standardized achievement tests to determine (young) children's current abilities, the use of valid tests enables teachers to identify the achievements of their pupils, allowing them to make some decisions about teaching and learning as to improve the learning experiences of all pupils Continued debate on the appropriate timing, amount and format of the assessment of children's early mathematical development is necessary.

Our results also question the effectiveness of Ecuadorian early mathematics instruction to enhance young children's early numerical abilities, as our study pointed to an overall low quality of early mathematics education (see below), which might help to account for the relatively small progress in early numerical abilities throughout the school year. The latter interpretation is in line with previous international reports, which suggests that many Kindergartners learn little or nothing throughout the school year, especially those who already possess basic number knowledge, due to the absence of appropriate learning opportunities (WRIGHT, 1991). Therefore, given their importance for school mathematics and everyday life, Ecuadorian Kindergarten instruction should focus on helping children acquire the numerical abilities stipulated in the national curriculum.

Next, in line with the assumption that the three major school types differ in their pupils' early numerical performances (BOJORQUE et al., 2015; PREAL, 2006), it was found that children in private schools outperformed children in public rural schools at both the start and the end of the Kindergarten year. These school type differences in children's performances at the start of Kindergarten might be explained by the differences in their SES (cf. JORDAN et al., 2006; STARKEY et al, 2004), as children from private schools came from a higher SES background than children from public rural schools. Unexpectedly, children from private and public rural schools did not differ in their progress in early numerical abilities towards the end of Kindergarten. The latter result cannot be explained by ceiling effects, given the substantial room 
for improvement in test scores (also for children in private schools) even at the end of the school year. As mentioned above and discussed in more detail below, this is most probably due to the overall low quality of mathematics education in the participating Kindergartens, ineffectively stimulating the development of both children who entered Kindergarten with lower and of children who started Kindergarten with higher levels of early numerical abilities.

\section{Quality of early mathematics education in Ecuadorian Kindergarten}

A second major finding involves the analysis of the quality of early mathematics education offered to Ecuadorian Kindergartners. Our study revealed a rather low quality of early mathematics education in all participating classrooms. Compared to previous studies conducted in North America (CLEMENTS et al., 2011; SARAMA et al., 2012), the classrooms in our study obtained mainly low COEMET scores (i.e., hardly 55, versus about 100 in the studies reported by Clements and colleagues). Contrasting effective teaching practices described in the literature (e.g., EPSTEIN, 2007; SARAMA; CLEMENTS, 2009b), we mainly observed an approach characterized by predominantly direct teaching, written worksheets and limited opportunities for the children to initiate activities, to interact with their peers and to reflect on their own strategies. The latter approach is more in line with teaching practices that have a negative impact on children's learning (MARCON, 2002). Although we observed no differences in the quality of early mathematics education between the three major school types, the quality of early mathematics education in public urban and public rural schools tended to be slightly more homogeneous than in private schools, suggesting greater qualitative variety within the latter school type.

Since this is the first study to systematically analyze the quality of early mathematics education in Ecuador, our findings provide new and important information on this topic. Although the consistency in our classroom observation scores and the high inter-rater reliability indicate a valid description of the educational practices in the participating classrooms, our results need to be complemented with those of future observation studies including more frequent classroom observations, teacher interviews and fine-grained qualitative analyses of interactions during instruction to validate our findings and to provide a more detailed description and understanding of the quality of current educational practices in early mathematics education in Ecuador. As the overall low quality seemed not beneficial for children's early numerical development, future intervention studies are additionally needed aiming at enhancing Ecuadorian Kindergartners' early numerical abilities via high-quality learning environments, such as the TRIAD/Building Blocks early childhood mathematics program (CLEMENTS; SARAMA, 2013), which has proven to be effective in North American countries. The results of these observation and intervention studies will not only offer important information for educational policy regarding the content of effective mathematics education in Ecuadorian Kindergarten; they will also inform educational practitioners about the characteristics of powerful learning environments for stimulating Ecuadorian children's early numerical abilities. 
The generally low quality of early mathematics education in the participating classrooms might be due to the characteristics of both pre-service and in-service teacher training in Ecuador, which have only marginal attention for both the core structures and processes involved in young children's mathematical development and the defining elements of powerful learning environments to effectively stimulate this development. Despite the efforts made by the Ecuadorian government for improving the quality of teacher training in Ecuador (ECUADOR, 2014), our results suggest that strengthened efforts are needed to ensure high-quality Kindergarten mathematics education in this country. Using methodologically sound observation instruments as the COEMET instrument, both strengths and weaknesses in current mathematics educational practices can be documented in view of providing building blocks for focused reforms in both Kindergarten classrooms and pre-service and in-service teacher training.

\section{Association between numerical abilities, SES, quality of early mathematics education and school type}

A third major finding relates to the influence of Ecuadorian children's numerical abilities at the start of Kindergarten, their SES, the quality of early mathematics education and school type on their numerical development towards the end of Kindergarten. First, consistent with prior findings (e.g., AUNIO; NIEMIVIRTA, 2010; JORDAN et al., 2009) we found a robust predictive relation between children's numerical abilities at the start of Kindergarten and their numerical development at the end of Kindergarten. These results (again) point to the importance of the early stimulation of children's numerical development during the preschool years, as a promising vehicle for their further mathematical development (JORDAN et al., 2009).

Second, and also in line with prior research (STARKEY et al., 2004), children's SES was predictively related to children's numerical abilities at the end of Kindergarten, with a higher level of maternal education resulting in a higher level of children's numerical abilities at the end of Kindergarten. However, the contribution of SES to children's early numerical development was considerably smaller than the contribution of their numerical abilities at the start of Kindergarten. This result is in line with previous studies indicating that the predictive power of Kindergartners' early numerical abilities was higher than the effects of demographic factors, including parent's education, for children's later mathematics achievement (AUNIO; NIEMIVIRTA, 2010). As we operationalized SES via only the mother's educational level, our results need to be confirmed in future studies which also use other SES indicators including family income or a composite score of both parents' education and family income (e.g., GALINDO; SONNENSCHEIN, 2015).

Third, an unexpected finding of our study is that the quality of early mathematics education did not contribute to the development of children's early numerical abilities. This result differs from previous studies evidencing the importance of highquality early mathematics education for children's mathematical development (e.g., CLEMENTS; SARAMA, 2008; CLEMENTS et al., 2012; FUSON, 2004). However, we are well aware that improving the quality of early mathematics education (for instance 
through intervention programs such as the one developed by Clements and associates) will not necessarily reduce the achievement gap between children from different SES levels. This may require an intervention that is particularly designed for this specific goal. Moreover, improving the quality of (mathematics) education at school constitutes only one of various factors that have shown to affect the development of children's numerical abilities. The broader socio-cultural context wherein different Ecuadorian schools operate as well as children's out-of-school environmental context (such as their home environment) are additional factors that may also affect children's learning (GALINDO; SONNENSCHEIN, 2015; LEFEVRE et al., 2010). That is why several early mathematics intervention programs that are particularly aimed at lower SES children will not only work on the improvement of mathematics education at school, but also work with children's families and neighborhoods (e.g., STARKEY et al., 2004). Future observation and intervention studies are required to disentangle the complex interplay between young children's early numerical abilities, the quality of mathematics education and the broader socio-cultural context. These studies will not only deepen our theoretical understanding of the complex interrelations between child-related, school-related and broader societal characteristics. They will also provide building blocks to design effective in- and out-of-school interventions that enhance all children's early numerical development.

Finally, the school type children attended had a positive but small effect on Ecuadorian children's numerical abilities at the end of Kindergarten. Although we observed no school type differences in children's early numerical progression from the start to the end of the school year when their initial early numerical abilities and SES were taken into account, the growth in public rural and public urban schools was slightly higher than in private schools. This finding is not in line with what is commonly assumed in Ecuadorian schools (cf. PREAL, 2006). Future studies including larger samples of schools are needed to validate and refine our findings.

\section{Conclusion}

Confirming previous findings in North American and European samples, we found a predictive relation between, on the one hand, Ecuadorian children's early numerical abilities and SES and, on the other hand, their further numerical development. These similarities indicate that the same individual (i.e., early numerical abilities at Kindergarten entry) and contextual factors (i.e., SES) underlie Kindergartners' early numerical development across different educational and cultural contexts. However, our study also pointed to an overall low quality of early mathematics education compared to North American and European settings, which might explain, on the basis of previous North American and European studies, the absence of evidence for the expected relation between the quality of Ecuadorian early mathematics education and Ecuadorian children's early numerical development. These results indicate that it is very important to optimize the quality of Ecuadorian early mathematics education in view of enhancing Ecuadorian children's early numerical development. The results of the present study and of the above mentioned 
future observation and intervention studies will contribute to research-informed decisions about how to best enhance Ecuadorian children's early numerical development and (consequently also) their acquisition of important mathematical skills up to the end of the elementary and secondary school years.

\section{References}

ANDERS, Yvonne et al. Preschool and primary school influences on the development of children's early numeracy skills between the ages of 3 and 7 years in Germany. School Effectiveness and School Improvement, v. 24, n. 2, p. 195-211, 2012.

AUNIO, Pirjo; NIEMIVIRTA, Markku. Predicting children's mathematical performance in grade one by early numeracy. Learning and Individual Differences, v. 20, n. 5, p. 427-435, 2010.

BOJORQUE, Gina et al. Early number and arithmetic performance of Ecuadorian 4-5-year olds. Educational Studies, V. 41, n. 5 , p. 565-586, 2015.

CARPENTER, Thomas P. et al. Using knowledge of children's mathematics thinking in classroom teaching: An experimental study. American Educational Research Journal, v. 26, n. 4, p. 499-531, 1989.

CLEMENTS, Douglas H.; SARAMA, Julie. Building Blocks-SRA, Pre-Kindergarten. Columbus: SRA/McGraw-Hill, 2013.

CLEMENTS, Douglas H.; SARAMA, Julie. Effects of a preschool mathematics curriculum: Summative research on the Building Blocks project. Journal for Research in Mathematics Education, v. 38, n. 2, p. 136-163, 2007.

CLEMENTS, Douglas H.; SARAMA, Julie. Experimental evaluation of the effects of a research-based preschool mathematics curriculum. American Educational Research Journal, v. 45, n. 2, p. 443-494, 2008.

CLEMENTS, Douglas H.; SARAMA, Julie. Mathematics knowledge of young children entering preschoolers in the U.S.

Far East Journal of Mathematical Education, v. 6, n. 1, p. 41-63, 2011.

CLEMENTS, Douglas H. et al. Longitudinal evaluation of a scale-up model for teaching mathematics with trajectories and technologies: persistence of effects in the third year. American Educational Research Journal, v. 50, n. 4, p. 812-850, 2013.

CLEMENTS, Douglas H. et al. Mathematics learned by young children in an intervention based on learning trajectories: a large-scale cluster randomized trial. Journal for Research in Mathematics Education, v. 42, n. 2, p. 127-166, 2011.

DE SMEDT, Bert; VERSCHAFFEL, Lieven; GHESQUIËRE, Pol. The predictive value of numerical magnitude comparison for individual differences in mathematics achievement. Journal of Experimental Child Psychology, v. 103, n. 4, p. 469-479, 2009.

DUNCAN, Greg J. et al. School readiness and later achievement. Developmental Psychology, v. 43, n. 6, p. 14281446, 2007.

ECUADOR, Ministerio de Educación. Archivo maestro de instituciones educativas AMIE. Quito: ME, 2013. Reporte de registros educativos 2013-2014. 
ECUADOR, Ministerio de Educación. Rendición de cuentas 2014. Quito: ME, 2014. Available in: <http://educacion.gob. ec/wp-content/uploads/downloads/2015/06/Rendicion-de-Cuentas-2014.pdf>. Access: 2016.

ENGLISH, Lyn D. Revealing and capitalising on young children's mathematical potential. ZDM Mathematics Education, v. 48, n. 7, 1079-1087, 2016.

EPSTEIN, Ann S. The intentional teacher: choosing the best strategies for young children's learning. Washington, DC: National Association for the Education of Young Children, 2007.

FUSON, Karen C. Pre-K to grade 2 goals and standards: Achieving 21st century mastery for all. In: CLEMENTS, Douglas H.; SARAMA, Julie; DiBIASE, Ann-Marie (Ed.). Engaging young children in mathematics: standards for early childhood mathematics education. Mahwah: Lawrence Erlbaum, 2004. p. 105-148.

GALINDO, Claudia; SONNENSCHEIN, Suzan. Decreasing the SES math achievement gap: initial math proficiency and home learning environments. Contemporary Educational Psychology, v. 43, p. 25-38, 2015.

GEARY, David C. Cognitive predictors of achievement growth in mathematics: A 5-year longitudinal study. Developmental Psychology, v. 47, n. 6, p. 1539-1552, 2011.

GINSBURG, Herbert P. Young children's mathematical minds. In: GINSBURG, Herbert P.; HYSON, Marilou; WOODS, Taniesha A. (Ed.). Preparing early childhood educators to teach math: professional development that works. Baltimore: Paul H. Brookers, 2014. p. 53-74.

HAYES, Andrew F. A primer on multilevel modeling. Human Communication Research, v. 32, n. 4, p. 385-410, 2006.

HIEBERT, James; GROUWS, Douglas A. The effects of classroom mathematics teaching on students' learning. In: LESTER Jr., Frank K. (Ed.). Second handbook of research on mathematics teaching and learning. Charlotte: Information Age, 2007. p. 371-404.

INEC. Instituto Nacional de Estadísticas y Censos. Encuesta de estratificación del nivel socioeconómico NSE 2011. Quito: [s. n.], 2011. Available at: <http://www.ecuadorencifras.gob.ec/encuesta-de-estratificacion-del-nivelsocioeconomico>. Access: 2016.

INEC. Instituto Nacional de Estadísticas y Censos. Informe de resultados ECV 2013-2014. Quito: [s. n.], 2014. Available at: <http://www.unicef.org/ecuador/150411-ResultadosECV.pdf>. Access: 2016.

INEVAL. Instituto Nacional de Evaluación Educativa. Ser estudiante 2013: primeros resultados nacionales. Quito: [s. n.], 2014.

JEYNES, William H. Standardized tests and Froebel's original kindergarten model. Teachers College Record, v. 108, n. 10, p. 1937-1959, 2006.

JORDAN Nancy $C$ et al. Early math matters: kindergarten number competence and later mathematics outcomes. Developmental Psychology, v. 45, n. 3, p. 850-867, 2009.

JORDAN Nancy $C$ et al. Number sense growth in kindergarten: a longitudinal investigation of children at risk for math difficulties. Child Development, v. 77, n. 1, p. 153-175, 2006.

KILDAY, Carolyn R.; KINZIE, Mable B. An analysis of instruments that measure the quality of mathematics teaching in early childhood. Early Childhood Education Journal, v. 36, n. 4, p. 365-372, 2009. 
LEFEVRE, Jo-Anne et al. Do home numeracy and literacy practices of Greek and Canadian parents predict the numeracy skills of kindergarten children? International Journal of Early Years Education, v. 18, n. 1, p. 55-70, 2010.

MARCON, Rebecca A. Moving up the grades: relationship between pre-school model and later school success. Early Childhood Research and Practice, v. 4, n. 1, 2002. Available in: <http://ecrp.uiuc.edu/v4n1/marcon.html>. Access: 2016.

NAEYC. National Association for the Education of Young Children. Early childhood curriculum, assessment, and program evaluation: building an effective, accountable system in programs for children birth through age 8 . Washington, DC: NAEYC, 2003.

PERRY, Robert; MacDONALD, Amy; GERVASONI, Ann (Ed.). Mathematics and transition to school: international perspectives. Singapore: Springer, 2015.

PIANTA, Robert et al. Features of pre-kindergarten programs, classrooms, and teachers: do they predict observed classroom quality and child-teacher interactions? Applied Developmental Science, v. 9, n. 3, p. 144-159, 2005.

PREAL. Calidad con equidad: el desafío de la educación ecuatoriana = Quality with equity: the challenge of the Ecuadorian education. Quito: Fundación Ecuador, 2006. Informe del progreso educativo. Educational progress report.

RAMANI Geetha B.; SIEGLER, Robert S. Reducing the gap in numerical knowledge between low- and middle-income preschoolers. Journal of Applied Developmental Psychology, v. 32, n. 3, p. 146-159, 2011.

SARAMA, Julie; CLEMENTS, Douglas H. Early childhood mathematics education research: learning trajectories for young children. New York: Routledge, 2009a.

SARAMA, Julie; CLEMENTS, Douglas H. Manual for classroom observation (COEMET). Version 3. [S. I.: s. n.], 2009b. Unpublished version.

SARAMA, Julie et al. Scaling up the implementation of a pre-kindergarten mathematics curriculum: teaching for understanding with trajectories and technologies. Journal of Research on Educational Effectiveness, v. 1, n. 2, p. 89-119, 2008.

SARAMA, Julie et al. The impacts of an early mathematics curriculum on oral language and literacy. Early Childhood Research Quarterly, v. 27, n. 3, p. 489-502, 2012.

SAYERS, Judy; ANDREWS, Paul. Foundational number sense: the basis for whole number arithmetic competence. In: ICMI STUDY PRIMARY MATHEMATICS STUDY ON WHOLE NUMBERS, 23., 2015, Macao. Proceedings... Macao: University of Macao, 2015. p. 124-131 Available in: <http://www.umac.mo/fed/ICMI23/doc/Proceedings_ICMI_ STUDY_23_final.pdf>. Access: 2016.

STARKEY, Prentice; KLEIN, Alice; WAKELEY, Ann. Enhancing young children's mathematical knowledge through a pre-kindergarten mathematics intervention. Early Childhood Research Quarterly, v. 19, n. 1, p. 99-120, 2004.

TERCE. Tercer Estudio Regional Comparativo y Explicativo. Logros de aprendizaje, Ecuador. Santiago, Chile: Unesco, 2015. Available in: <http://www.unesco.org/new/fileadmin/MULTIMEDIA/FIELD/Santiago/pdf/Ficha-Logros-delAprendizaje-Ecuador.pdf>. Access: 2016.

UNITED NATIONS. World economic situation and prospects 2016. New York: [s. n.], 2016. 
VAN DE RIJT, B. A. M; VAN LUIT, J. E. H; PENNINGS, Albert H. The construction of the Utrecht early mathematical competence scales. Educational and Psychological Measurement, v. 59, n. 2, p. 289-309, 1999.

WAGER, Anita A.; GRAUE, M. Elizabeth; HARRIGAN, Kelly. Swimming upstream in a torrent of assessment. In: PERRY, Robert; MacDONALD, Amy; GERVASONI, Ann (Ed.). Mathematics and transition to school: international perspectives. Singapore: Springer, 2015. p. 15-30.

WRIGHT, Bob. What number knowledge is possessed by children beginning the Kindergarten year of school? Mathematics Education Research Journal, v. 3, n. 1, p. 1-16, 1991.

Received on May 19th, 2016 Approved on February 22nd, 2017

Gina Bojorque obtained the PhD degree at the Center for Instructional Psychology and Technology at KU Leuven. She is a lecturer at the University of Cuenca. Her major research interest focuses on early mathematics learning and instruction.

Joke Torbeyns is a Postdoctoral Fellow of the Center for Instructional Psychology and Technology at the KU Leuven. Her research interests focus on the acquisition of early numeracy competencies and on strategy choice and development in the domain of elementary arithmetic.

Daniël Van Nijlen works at the Center for Educational Effectiveness and Evaluation at the $\mathrm{KU}$ Leuven and is involved in national assessments of educational standards in Flanders, Belgium. His primary research interests are educational measurement and psychometrics.

Lieven Verschaffel is a full professor in educational sciences working at the Center for Instructional Psychology and technology at the KU Leuven. His major research interests are educational psychology and (psychology of) mathematics education. 